\title{
FIELD WORK SUPPLEMEN'TING PHOTOGEOLOGICAL INTERPRETATION OF NÛGSSUAQ
}

\author{
G. Henderson
}

In early 1967 the writer was given the task of undertaking a photointerpretation of the areas that make up the $1: 100000$ geological map sheets $70 \mathrm{~V} .1 \mathrm{~N}$ Agatdal and $70 \mathrm{~V} .1 \mathrm{~S}$ Qutdligssat. The object of the photointerpretation was to see whether, with the additional structural and lithological information obtainable from the aerial photos, it would be possible to complete the geological maps at this scale using the existing 1 : 50000 geological field maps. These field maps were compiled on the basis of field work carried out over the years by expeditions to this part of Greenland led by Professor A. Rosenkrantz, University of Copenhagen.

The photointerpretation revealed much additional detail on the structure of the Tertiary basalts in this part of Greenland. This supplemented existing knowledge of the structure (see Rosenkrantz and Pulvertaft, in press; V. Münther, report in preparation). In particular, the interpretation showed in detail the pattern of block faulting that has affected the basalts of north-western Nugssuaq, Hareфen and western Disko. Because of the magnetite content of the basalts, measurements of the strikes of the flows are difficult to obtain in the field. Strikes in the areas mentioned are very clear on the aerial photos. In addition, numerous dip measurements were made under the stereoscope using a technique based on methods described by Lattman and Ray (1965) and Allum (1966). The photos also showed in considerable detail the numerous dykes that are present in parts of the area. Because of the strong relief and relative inaccessibility of much of the area, the plotting of the many dykes had presented a problem in the field.

Difficulty was experienced in distinguishing the lithologies in the block-faulted zone, and these difficulties could not be resolved on the basis of the existing field information. Although the aerial photos, and in particular the oblique photos, showed much lithological detail in the structurally simpler part of Nugssuaq east of the block-faulted zone, there were certain areas, 
such as the area west of Ikorfat on the north coast and the Itivdle valley and its eastern branches, where the lithology and structure could not be represented in the detail considered necessary on the basis of existing field maps and photointerpretation. It was therefore considered advisable to undertake a series of field checks in connection with the photointerpretation in parts of the area. Because of the limited time available, the field work was confined to Nugssuaq. During the summer the writer had the pleasure of working together with a team led by Professor Rosenkrantz.

The general geology of the area is covered in recent papers by Rosenkrantz and Pulvertaft (in press) and Münther (report in preparation). Their accounts include a comprehensive list of earlier publications on the area.

The field investigation of the block-faulted zone north-west of the Itivdle valley provided additional evidence on the nature of the fault pattern in this area. The Itivdle valley marks a fault zone trending NE-SW, with fault contacts along the north-western side between the Cretaceous-Tertiary sediments and the picritic and olivine-rich basalts, and between these basalts and the plagioclase-porphyritic basalts. As mentioned by Münther (report in preparation) good marker horizons in the basalts are few, but the contrast between the lowest, olivine-rich basalts and the plagioclase-porphyritic basalts is clear when these two types are in fault contact with each other. In addition, some series of flows have sufficient distinguishing characters to permit recognition of the amount of displacement of each side of a fault. In this part of Nugssuaq there is a zone of brown, softer-weathering plagioclase-porphyritic basalts between the lowest grey or olive-grey, softweathering olivine-rich basalts and the highest red-brown massive, columnarjointed plagioclase-porphyritic basalts. This serves as a useful marker zone in the northern and southern parts of the faulted area. The intrabasaltic sediment and tuff horizon is also useful in delimiting the fault blocks.

The fault pattern is very complex. The main Itivdle faults have resulted in downthrow to the north-west, but within the block-faulted area there are faults with a variety of directions. Some of these are antithetic faults with downthrow to the south-east, so that there are considerable repetitions of parts of the basalt sequence. 
The area east of Itivdle is structurally much simpler. A fault with a displacement of several hundred metres runs from Ikorfat on the north coast south-east through the area east of the Navssât valley in central Nugssuaq. This fault, which is a normal fault with downthrow to the south-west, has been active on more than one occasion, as mentioned by Rosenkrantz and Pulvertaft (in press). West of this fault a gentle syncline is developed. This seems to be due to a sagging of the rocks west of the fault. In the coast section west of Ikorfat there has been extensive landslip of volcanic rocks downhill. This feature was examined in the field.

In much of Nugssuaq east of the Itivdle valley the volcanic sequence starts with rocks laid down in a subaqueous environment for which the term pillow breccia has been suggested. In many areas, at levels above the basal pillow breccias, there is very clear evidence of the effects of the interplay of subaerial and subaqueous environments in determining the nature of the volcanic rocks laid down. It is hoped that detailed compilation will permit something to be said about the configuration and history of the basin in which these pillow breccias are found.

The boundary of the large intrusive picrite between the Itivdle valley and the north coast is difficult to see on the aerial photos, but a trip into the Tunorssuaq valley and good views of the south-eastern side of the valley provided additional information on this. An area of picrite with identical appearance in the field was mapped on the coast on the eastern side of the southern entrance to Itivdle.

In the Tunorssuaq area there are numerous carbonate-rich dykes in a zone along the boundary between the picrite and the sediments. Some of these dykes are clearly intrusive into picrite. Little work has been done on these dykes so far, but in some of them the presence of carbonate is due to a late carbonatization.

Another feature in the area is the presence of spectacular zones of alteration in the country rock where doleritic or basaltic dykes intrude the picrite or the pillow breccias. One such alteration zone on one side of a dyke west of Niaqornat was found to have a width of $6 \mathrm{~m}$.

Field checks of the dips in basalts measured under the stereoscope showed that the method used gives very good results. 
References

Allum, J.A.E. (1966) Photogeology and regional mapping. Pergamon Press.

Lattman, L. H. and Ray, R.G. (1965) Aerial photographs in field geology. Holt, Rinehart and Winston.

Rosenkrantz, A. and Pulvertaft, T.C.R. (in press) Cretaceous-Tertiary stratigraphy and tectonics in northern West Greenland. Amer.Ass. Petrol. Geol., Memoir 12.

\section{PRELIMINARY NOTES ON THE TERTIARY LAVAS OF NORTHERN DISKO}

\section{Asger Ken Pedersen}

A study on the lavas of northern Disko has recently been started. V. Münther has kindly lent the writer samples of Disko lavas collected on the earlier Nugssuaq expeditions. Apart from the pioneering work by Steenstrup (1882, 1901) very little has been published on the lavas from this region. Extensive literature exists on the rocks containing telluric iron but cannot be cited here.

During the summer of 1968 reconnaissance mapping and sample collection were undertaken in northern Disko from Vaigat in the north to Nordfjord and Stordal in the south. Both in the field and in the laboratory special attention was paid to lavas contaminated by reaction with pre-Tertiary sedimentary and metamorphic rocks.

The rocks underlying the volcanic sequence consist of Cretaceous sandstones and bituminous shales, and Precambrian gneisses and amphibolites. In Stordal the lavas can be seen to have buried hills consisting of weathered Precambrian metamorphic rocks. The beginning of the volcanism is characterized by the formation of subaqueous pillow breccias of picritic 